Article

\title{
Corsican Pine (Pinus laricio Poiret) Stand Management: Medium and Long Lasting Effects of Thinning on Biomass Growth
}

\author{
Rodolfo Picchio ${ }^{1, *}\left(\mathbb{D}\right.$, Rachele Venanzi ${ }^{1}$, Francesco Latterini ${ }^{1}$, Enrico Marchi ${ }^{2}$, \\ Andrea Laschi ${ }^{2}$ (D) and Angela Lo Monaco ${ }^{1}$ (D) \\ 1 Department of Agriculture and Forest Sciences (DAFNE), Tuscia University, 01100 Viterbo, Italy; \\ venanzi@unitus.it (R.V.); francesco.latterini@libero.it (F.L.); lomonaco@unitus.it (A.L.M.) \\ 2 Department of Agriculture (GESAAF), Florence University, 50144 Florence, Italy; \\ enrico.marchi@unifi.it (E.M.); andrea.laschi@unifi.it (A.L.) \\ * Correspondence: r.picchio@unitus.it; Tel.: +39-0761-357-400
}

Received: 10 April 2018; Accepted: 7 May 2018; Published: 10 May 2018

\begin{abstract}
With the aim of acquiring better comprehension of the ecological and productive aspects of the management of pine forests, we monitored logging damage and evaluated the effects of thinning on stand growth 20 years after the treatment in a Pinus laricio Poiret stand in central Italy. The objectives of the present study were to estimate the injury levels to the remaining trees after thinning; to assess logging damage in the long-term by monitoring residual trees at the end of thinning; to evaluate the effect of damage on the radial growth of trees; to assess the stand dynamics in relation to injury levels and the treatment applied in a twenty-year range; to understand a possible treatment return time; and to evaluate the existence of the "thinning shock". The results were that 20 years after treatment, the stand dynamics showed a complete recovery; logging damage did not affect the radial growth of $P$. laricio over time; a second treatment seem to be sustainable starting from the fifteenth year after the previous treatment; and the thinning shock can be clearly evaluated in the first six to seven years after the treatment.
\end{abstract}

Keywords: stand growing; thinning shock; forest logging; tree wounds; tree ring width

\section{Introduction}

The functionality and resilience of forest ecosystems are strictly related to forest structure [1-3], which represents the distribution of biomass, i.e., the vertical and horizontal spatial arrangement of plant species, tree sizes, age distribution, and tree canopy layering. Stand structure attributes are increasingly recognized to be of theoretical and practical importance in analyzing the management quality in forest ecosystems. In general, the characteristics of forest cover are closely related to stand density, stand age, and species composition and are altered by natural disturbances or anthropogenic interference such as forest management practices. Among the various forest management practices, the thinning or removal of some trees from the forest is widely conducted to produce more valuable and large-diameter timber. It reduces competition among the remaining trees, reduces the risk of fire [4], and helps to maintain a healthy forest [5].

Considering that in the last fifty years, Mediterranean forests have experienced a rapid expansion of pioneer conifer stands driven by natural colonization after land abandonment in SE France [6] or afforestation efforts in SE Spain [7] and in Italy [8], forest fires and pest outbreaks are predicted to increase in the future, also due to the impact of climate changes on drought and extreme weather events $[9,10]$. As already mentioned, the appropriate silvicultural treatments play a key role in increasing the resistance and resilience of Mediterranean forests to environmental perturbations [11,12]. 
Structural changes in the forest canopy due to thinning alter the microclimatic conditions within the forest [13-17]. These microclimatic changes could improve the growth conditions for the remaining trees and understory species $[13,18]$. However, a short- and medium-term decline in the growth of remaining trees, called "thinning shock," has also been reported for some forest stands and species [19-21].

Furthermore, the positive changes due to thinning could be offset by high vulnerability to insect damage and mortality, which might be caused by trunk or root damage during the thinning procedure [22,23]. For these reasons, the methodologies of felling, processing, and extraction need to be planned on a larger scale; they cannot be sporadic events, not connected to the social, environmental, and economic contexts. The forest operations have to be planned during the implementation and execution of the working phases [24].

Research on the damage caused by forest operations to the remaining trees and/or to regeneration in forest stands started at the beginning of the twentieth century and is more important as the use of mechanized wood harvesting has been increasing $[21,25,26]$. Logging injury to the remaining trees may lead to serious economic losses in terms of timber quality at the final harvest, wood losses in the damaged trees, and tree growth reduction [27]. Long term effects may significantly reduce the benefits of commercial thinning [21,25]. Other forest ecosystem services, e.g., carbon sequestration, soil protection, and water control, may also be affected.

The effect on tree growth of logging mechanical damage to the stems remains unclear, although some authors have conducted detailed studies [21,28]. Moreover, for Mediterranean pine plantations, there are some knowledge gaps regarding the late first thinning effect on tree growth. Studies on this topic are still limited and the long-term effects of damage are not well known [29].

Analysis of the annual growth rings can be used as an "environmental archive" [30,31] and as an indicator of growth changes showing the effect of silvicultural treatments.

With the aim of acquiring a better comprehension of some ecological and productive aspects of the management of pine forests, logging damage was monitored and the effects of thinning on stand growth 20 years after the treatment were evaluated in a Pinus laricio Poiret stand in central Italy. Specifically, the aims of this study were an extension of previous work [21] developed ten years ago, with the following objectives: (1) to estimate the injury levels to the remaining trees after thinning; (2) to assess logging damage in the long-term by monitoring residual trees at the end of thinning; and (3) to evaluate the effect of damage on the radial growth of trees. In the present study, further investigations were carried out on the same stand in order to assess the stand dynamics in relation to the injury levels and the treatment applied in a twenty-year range. This continuing research was aimed at assessing the effect of damage on the radial growth of trees; at understanding a possible treatment return time; and evaluating the existence of "thinning shock".

Understanding all of these aspects is a key factor in the ecological management of Corsican pine forests located in the Mediterranean area and is an important factor in supporting the decision making of forest managers.

\section{Materials and Methods}

\subsection{Area Description}

The study was carried out in a forest located in Grottone (Viterbo-Central Italy- $42^{\circ} 23^{\prime} 35.58^{\prime \prime} \mathrm{N}$, $12^{\circ} 10^{\prime} 25.52^{\prime \prime} \mathrm{E} 720 \mathrm{~m}$ a.s.l.). The stand was an even-age, P. laricio (Corsican pine) forest, thinned in 1998. This forest originated from a plantation established in the 1970s on a mostly flat terrain (maximum slope gradient $10 \%$ ). Seedlings were two to five years old at planting time and the plantation scheme was rectangular $(2 \mathrm{~m} \times 2.5 \mathrm{~m})$, with a density of about 2000 trees/ha.

The climate of the area is moist temperate, with a mean annual precipitation of $1180 \mathrm{~mm}$, mean annual temperature of $12.8^{\circ} \mathrm{C}$, and mean summer precipitation of $55 \mathrm{~mm}$; the driest month is July $(30 \mathrm{~mm})$, the temperature of the warmest month is $22.0^{\circ} \mathrm{C}$, and the temperature of the coldest month is $4.2^{\circ} \mathrm{C}$. Data were the averages over the period 1916-2010 at the San Martino al Cimino weather 
station (510 $\mathrm{m}$ a.s.l., less than $5 \mathrm{~km}$ from the study area). The soil, formed on a volcanic parent material, is sandy loam, slightly acid, and showed a well-structured, humus-rich A horizon.

As described in a previous paper [21], the silvicultural treatment used was selective thinning from below, carried out in the spring of 1998 on about 32 ha. For research purposes, an adjacent control area of about 6 ha was not treated. Logging operations were carried out with a semi-mechanized logging system, felling and processing by a chainsaw, and bunching and extraction by skidding with a tracked agricultural tractor (crawler). The skidding performed was inter-row and only one of two inter-rows was used as a skid trail. Reference [21] described the detailed working cycle: felling of two or more trees; bunching by the tractor (average distance $33 \mathrm{~m}$ ); partial delimbing (on about $3 / 4$ of the tree circumference); topping; and skidding to the landing (average distance was about $73 \mathrm{~m}$; average load for skidding trip was $0.87 \mathrm{t}$, for an average skidding speed of about $1.4 \mathrm{~km} / \mathrm{h}$ ).

\subsection{Data Collection}

Data collection was carried out for the first time in 1998 through a design-based approach, a statistical approach that establishes the choosing methods and using of the sites, allowing possible pseudoreplication problems to be overcome [32]. The subsequent data records were made before and after thinning, in 2008 and in 2017, in 25 circular plots of $1256 \mathrm{~m}^{2}$ (dendrometric plots DP) in the treated area (total surface $31,400 \mathrm{~m}^{2}$ ) and in five DPs in the control area (total surface $6280 \mathrm{~m}^{2}$ ). Plots were randomly selected, at a $>30 \mathrm{~m}$ distance from the edge of the treated and control areas. No thinning or other important disturbance were carried out in the time between 1998 and 2017.

For the three temporal field analyses (1998-2008-2017), after the measurements of the main dendrometric characteristics, the growing stock was estimated with a two-way table [33], developed for Pinus laricio of Tuscany and the slenderness ratio (average value of $\mathrm{H} / \mathrm{DBH}$ of each trees) was calculated as an index of stand stability [34].

Tree damage was detected in four rectangular plots $(10 \mathrm{~m} \times 250 \mathrm{~m}$ wound plots WP). In 1998, these WP and all damaged trees were numbered and marked. The field analysis repetitions were done in 2008 and 2017. The following parameters were recorded: DBH of all the trees; crown class of all the trees; type of damaged tissues; cause of damage; location of wounds, in meters above ground level; and size of wounds, by measuring maximum length and width by a ruler ( $1 \mathrm{~mm}$ accuracy) and calculating the ellipse surface area. Type and size of damage were used as the classifications in two damage classes, i.e., severe (wood wound $>200 \mathrm{~cm}^{2}$ size) and light (bark/bast wound $<200 \mathrm{~cm}^{2}$ size), according to $[21,35]$. Trees damaged in several parts were classified on the basis of the most severe damage. The agent of damage (felling, skidding) was classified in 1998.

In May-July 2008 and 2017, stem core samples were collected at breast height on the north side of two trees per DP in each of the seven 5-cm diameter classes (from 15 to $50 \mathrm{~cm}$ ) by using a Pressler increment borer. In the thinned area, stem core samples were collected from one damaged and one undamaged tree in each DP. Ring width was measured by using Aniol Dendroware, with an accuracy of $0.01 \mathrm{~mm}$. In order to check the differences in growth among the damaged, undamaged, and control trees, different numbers of rings were considered: all rings before thinning (BT); ten rings before thinning (TBT); post thinning 2008 (ten rings TPT1); and post thinning 2017 (twenty rings TPT2). In order to evaluate the differences at the stand level, the yearly weighted ring width (YWW) was calculated as a mean of yearly ring width weighted on the basis of the frequency distribution of trees per diameter class in 2008 and in 2017.

\subsection{Statistical Analysis}

Statistical analyses were carried out using the Statistica 7.1 (2007) software (StatSoft Inc., Tulsa, OK, USA). After checking for normality (Kolmogorov-Smirnov test) and homogeneity of variance (Levene test), the $t$-test was applied to all dendrometric parameters. Two-way ANOVA was applied to DBH and the number of trees to test the effect of year and the factors "damaged and undamaged", "severity", or "agent". The post-hoc Tukey-HSD test was used to compare the significance of differences among 
the means. Factorial ANOVA was applied to the ring width to test the effect of the number of rings (BT, TBT, TPT1, TPT2), diameter class, and the thinning and damage effect (trees in control area, undamaged, and damaged trees in thinned area). The post-hoc Tukey HSD test per unequal N was used to compare the significance of differences among the means. The Kruskal-Wallis non-parametric multiple-comparison test was used to test the effect of the factor "position" on DBH and the number of damaged trees in every year (1998 and 2008).

In order to determine the relationship between DBH, damage agent (felling, skidding), position (roots or stem at different levels above ground), and severity (light, severe), a nonparametric correlation analysis (Spearman correlation matrix) was applied. Nonlinear regression analysis between ring width (dependent variable) and year (independent variable), for damaged (TD) and undamaged (TU) trees and the trees from the control area $(\mathrm{C})$, was applied. The Wilcoxon non-parametric test was used to test the differences in YWW before and after thinning between the control and damaged; control and undamaged; and damaged and undamaged trees. Non-metric multidimensional scaling (NMDS) was used to show the differences in the average ring width per diameter class for the trees in the control area (C), for damaged trees (TD), and for undamaged trees (TU) in the thinned area.

\section{Results}

As reported in the previous step of this research by [21], about $20 \%$ of the volume, $38 \%$ of trees, and $26 \%$ of the basal area were removed by the treatment; the basal area before thinning was in fact $56.5 \mathrm{~m}^{2} \mathrm{ha}^{-1}$, and after thinning, it was $41.9 \mathrm{~m}^{2} \mathrm{ha}^{-1}$. Regarding the dendrometric situation before the treatment, no statistically significant difference was recorded between the thinned areas and control (Table 1). The treatment effect in the year of the thinning (1998) led to some significant changes in most of the dendrometric parameters. DBH and tree height were significantly increased (Table 1). Tree density, basal area, growing stock, and slenderness ratio were significantly decreased (Table 1). In detail, the changes due to the thinning and their development during the last two decades are shown in Table 1 . The number of trees recorded in 1998 decreased in the thinned area by about $23 \%$ and $26 \%$ in 2008 and 2017, respectively. In the control area, the reduction was 13\% in 2008 and $14 \%$ in 2017. The reduction in the number of trees was mainly due to trees that were uprooted or broken off by wind or snow. The tree reduction recorded in about twenty years in the thinned area was mainly due to the death of undamaged ( $84.8 \%$ of dead trees) rather than damaged trees (15.2\%). The DBH increase recorded in 2017 was about $+54 \%$ higher than that in 1998 after thinning, thus maintaining the positive trend shown in 2008. The decrease of basal area recorded in the thinned area in 1998 and 2008 ( $26 \%$ and $1 \%$, respectively), changed trend completely in 2017 , showing an increase of $28.5 \%$, similar to that recorded for the control area (31.9\%), although the highest value was in the thinned area (Table 1). The average tree height and growing stock showed an important increase. Tree height showed no statistical difference between the thinned and control areas in 2017; growing stock increased similarly to that of the control area over time, showing a lower statistical difference. The slenderness ratio in 2017 significantly decreased (15\%) (Table 1) in the thinned area, while it increased in the control area $(2 \%)$ relative to 1998 (Table 1$)$.

From 1998 to 2017, 270 trees died in the WPs (wound plots) (Table 2), i.e., a further 50 trees in comparison with 2008. The dead trees consisted of 230 undamaged trees $(26.2 \%$ of the total undamaged trees) and 40 damaged trees (29\% of the total damaged trees).

Immediately after thinning, $13.6 \%$ of the standing trees showed damage (Table 2 ) and $36.2 \%$ of the damaged trees showed severe injuries (Table 3). As found ten years after thinning, no wound was completely healed in 2017. In 2017, the percentage of damaged trees was about $17.9 \%$, and out of this, $87.2 \%$ showed severe wounds (Table 3). These results were partially concordant with the data of 2008 (17.0\% of damaged trees and $86.7 \%$ with severe wounds). 
Table 1. Dendrometric parameters before and after thinning $(1998 ; 2008 ; 2017)$ (mean \pm SD)

\begin{tabular}{|c|c|c|c|c|c|c|c|c|c|c|c|c|}
\hline \multirow{2}{*}{ Dendrometric Parameters } & \multicolumn{3}{|c|}{ Before Thinning 1998} & \multicolumn{7}{|c|}{ After Thinning } & \multicolumn{2}{|c|}{ Control Area } \\
\hline & Control & Thinned & A & 1998 & B & 2008 & $\mathrm{C}$ & 2017 & D & $\mathbf{E}$ & 2017 & $\mathbf{F}$ \\
\hline Growth rings at breast height (N.) & $22 \pm 1.7$ & $22 \pm 1.9$ & ns & $22 \pm 1.9$ & ns & $32 \pm 2.3$ & $* * *$ & $40 \pm 0.5$ & $* * *$ & $* *$ & $40 \pm 0.6$ & ns \\
\hline Trees $\left(\right.$ N. ha $\left.{ }^{-1}\right)$ & $1585 \pm 7.5$ & $1600 \pm 11.3$ & ns & $988 \pm 12.9$ & $* * *$ & $764 \pm 19.6$ & $* * *$ & $726 \pm 10.2$ & ** & * & $1368 \pm 15.7$ & $* * *$ \\
\hline $\mathrm{DBH}^{\mathrm{a}}(\mathrm{cm})$ & $20.8 \pm 0.6$ & $21.2 \pm 0.9$ & ns & $23.2 \pm 1.1$ & $* *$ & $30.5 \pm 1.8$ & $* *$ & $35.7 \pm 0.8$ & $* * *$ & * & $25.7 \pm 0.9$ & ** \\
\hline Basal area $\left(\mathrm{m}^{2} \mathrm{ha}^{-1}\right)$ & $53.9 \pm 1.1$ & $56.5 \pm 0.9$ & ns & $41.9 \pm 2.1$ & $* *$ & $55.8 \pm 3.6$ & $* *$ & $72.6 \pm 4.1$ & $* * *$ & $* *$ & $71.1 \pm 10.2$ & * \\
\hline Tree height (m) & $14.1 \pm 0.7$ & $14.4 \pm 1.2$ & ns & $15.0 \pm 0.7$ & $*$ & $20.6 \pm 1.3$ & $* *$ & $24.4 \pm 1.1$ & $* * *$ & $* *$ & $24.3 \pm 0.6$ & ns \\
\hline Growing stock $\left(\mathrm{m}^{3} \mathrm{ha}^{-1}\right)$ & $395 \pm 10.5$ & $410 \pm 8.2$ & ns & $329 \pm 5.4$ & * & $610 \pm 6.1$ & $* *$ & $827 \pm 4.1$ & $* * *$ & $* *$ & $797 \pm 6.5$ & * \\
\hline Slenderness ratio $b$ & $87 \pm 1.6$ & $86 \pm 0.9$ & ns & $83 \pm 1.8$ & * & $78 \pm 0.7$ & $* *$ & $73 \pm 0.9$ & $* *$ & * & $89 \pm 2.6$ & $* * *$ \\
\hline
\end{tabular}

$t$-test applied to: A, thinned (25 DP) vs. control areas (5 DP) in 1998; B, thinned areas before (25 DP) and after thinning (25 DP) in 1998; C, thinned areas in 1998 (25 DP) and 2008 (25 DP);

D, thinned areas (25 DP) and 2017 (25 DP); E, thinned areas in 2008 (25 DP) and 2017 (25 DP); F, thinned (25 DP) and control (5 DP) areas in 2017 . ${ }^{a}$ calculated by means of the average value

of the basal area of each tree; ${ }^{\mathrm{b}}$ average value of $\mathrm{H} / \mathrm{DBH}$ of each tree. ${ }^{*} p \leq 0.05 ;{ }^{* *} p \leq 0.01 ; * * * \leq 0.001$; ns $=$ not significant. 
The DBH of the damaged trees was significantly higher in 1998 than the DBH of undamaged trees, but for this parameter in 2017, no statistical difference was found (Table 2).

Table 2. Damage to trees and diameter at breast height $( \pm S D)$ after thinning in 1998, 2008, and 2017.

\begin{tabular}{ccccc}
\hline Tree Condition & Year & DBH $\mathbf{( c m})$ & Trees $_{\mathbf{~ N . ~ h a}}{ }^{\mathbf{- 1}}$ ) & Dead Trees (N. ha $^{\mathbf{- 1}}$ ) \\
\hline Undamaged & 1998 & $20.8 \mathrm{a} \pm 0.1$ & $877 \mathrm{a} \pm 30$ & \\
Damaged & 1998 & $22.1 \mathrm{~b} \pm 0.5$ & $138 \mathrm{~b} \pm 7$ & \\
Undamaged & 2008 & $30.9 \mathrm{c} \pm 0.2$ & $660 \mathrm{c} \pm 20$ & $182 \pm 50.4$ \\
Damaged & 2008 & $29.8 \mathrm{c} \pm 0.6$ & $135 \mathrm{~b} \pm 19$ & $38 \pm 8.3$ \\
Undamaged & 2017 & $35.7 \mathrm{~d} \pm 0.3$ & $612 \mathrm{c} \pm 12$ & $230 \pm 25.1$ \\
Damaged & 2017 & $34.9 \mathrm{~d} \pm 0.9$ & $133 \mathrm{~b} \pm 11$ & $40 \pm 6.1$ \\
ANOVA $p$-value & & & & \\
Damage & & 0.902 & $<0.001$ & \\
Year & & $<0.001$ & $<0.001$ & \\
Damage $\times$ Year & & $<0.01$ & $<0.05$ & \\
\hline
\end{tabular}

Different letters show significant differences among values in a column (Tukey test, $\mathrm{N}=4$ wound plots).

The DBH of trees with severe or light damage did not show statistical differences (Table 3).

Some logging damage developed over time, and therefore delayed damage due to undetectable injuries was only recognized sometime after the thinning. However, the disclosure of "hidden" wounds, due to impacts, as shown in Table 3, is closely linked to the first ten years after the damaging event.

Significant differences were recorded by [25] in the number of damaged trees in relation to the damage agent (Table 4). In particular, damage to standing trees was mainly caused by skidding and bunching ( $81.2 \%$ of damaged trees); about $14.5 \%$ of trees were damaged by felling and only $4.3 \%$ showed injuries due to both felling and bunching/skidding. The damage agent had no significant incidence on tree death from 1998 to 2017; as shown in Table 4, the death rate of 25\% was similar between the felling and skidding damage agents, and only multiple damage was strictly related to tree death $(100 \%)$. Tree mortality was greater in the first 10 years of the survey and then decreased.

Table 3. Damage severity in trees and diameter at breast height $( \pm$ SD) after thinning in 1998, 2008, and 2017.

\begin{tabular}{|c|c|c|c|c|c|}
\hline Damage Severity & Year & DBH (cm) & Trees (N. ha ${ }^{-1}$ ) & Dead Trees (N. ha ${ }^{-1}$ ) & Variation 1998-2017 (N. ha $\left.{ }^{-1}\right)$ \\
\hline Light damage & 1998 & $22.0 \mathrm{a} \pm 0.6$ & $88 a \pm 13$ & & \\
\hline Severe damage & 1998 & $22.0 \mathrm{a} \pm 0.5$ & $50 b \pm 8$ & & \\
\hline Light damage & 2008 & $30.7 \mathrm{~b} \pm 1.1$ & $18 \mathrm{c} \pm 11$ & $28 \pm 8.6$ & $-42 \pm 5.1$ \\
\hline Severe damage & 2008 & $29.7 \mathrm{~b} \pm 0.5$ & $117 \mathrm{~d} \pm 11$ & $10 \pm 2.3$ & $+77 \pm 4.8$ \\
\hline Light damage & 2017 & $36.1 \mathrm{c} \pm 1.4$ & $17 \mathrm{c} \pm 11$ & $29 \pm 8.4$ & $-42 \pm 5.1$ \\
\hline Severe damage & 2017 & $35.1 \mathrm{c} \pm 0.6$ & $116 \mathrm{~d} \pm 11$ & $11 \pm 1.6$ & $+77 \pm 4.8$ \\
\hline \multicolumn{6}{|l|}{ ANOVA $p$-value } \\
\hline Severity & & 0.122 & $<0.001$ & & \\
\hline Year & & $<0.001$ & 0.420 & & \\
\hline Severity $\times$ Year & & 0.081 & $<0.001$ & & \\
\hline
\end{tabular}

Different letters show significant differences among values in a column (Tukey test, $\mathrm{N}=4$ wound plots).

At the time of thinning (Table 5), about $40.6 \%$ of the damage was located at the stem base, $39.1 \%$ between $0.3 \mathrm{~m}$ a.g.l. and $1 \mathrm{~m}$ a.g.l. (above ground level), and $10.9 \%$ at more than $1 \mathrm{~m}$ a.g.l. Only $2.9 \%$ of trees showed recognizable root damage and $6.5 \%$ showed damage in several parts. In 2017, all trees with damage to roots or several parts died, $56.4 \%$ showed damage at the stem base, $36.1 \%$ between $0.3 \mathrm{~m}$ a.g.l. and $1 \mathrm{~m}$ a.g.l., and only $7.5 \%$ showed damage at more than $1 \mathrm{~m}$ a.g.l. Damage usually occur right after the treatment, but sometimes developed over time. In this study, 35 trees classified as undamaged in 1998 showed severe damage in 2008. The other 42 trees classified as lightly damaged in 1998 showed severe wounds in 2008 . These variations may be explained by a late damage effect, i.e., some trees were hit during logging but did not show clear and recognizable damage in 1998. 
Table 4. Damage agent in trees and diameter at breast height $( \pm$ SD) after thinning in 1998 and dead trees in 2017.

\begin{tabular}{ccccc}
\hline Damage Agent & Year & DBH $\mathbf{( c m )}$ & Trees $\left.\mathbf{( N . ~ h a} \mathbf{~}^{\mathbf{1}}\right)$ & Dead Trees in Year 2017 (N. ha $^{\mathbf{- 1}}$ ) \\
\hline Felling & 1998 & $21.2 \pm 1.3$ & $20 \mathrm{~b} \pm 11$ & $5 \pm 2.3$ \\
Skidding & 1998 & $22.1 \pm 0.6$ & $112 \mathrm{a} \pm 9$ & $28 \pm 3.1$ \\
Both & 1998 & $21.8 \pm 4.2$ & $6 \mathrm{c} \pm 2$ & $7 \pm 1.1$ \\
ANOVA $p$-value & & & & \\
Agent & & 0.389 & $<0.001$ & \\
\hline
\end{tabular}

Different letters show significant differences among values in a column (Tukey test, $\mathrm{N}=4$ wound plots).

Table 5. Damage position in trees and DBH ( \pm SD) after thinning in 1998, 2008, and 2017.

\begin{tabular}{|c|c|c|c|c|}
\hline Damage Position & Year & DBH (cm) & Trees (N. ha ${ }^{-1}$ ) & Dead Trees (N. ha ${ }^{-1}$ ) \\
\hline Roots & 1998 & $23.8 \pm 5.4$ & $4 a \pm 3$ & \\
\hline Stem base & 1998 & $22.2 \pm 0.3$ & $56 \mathrm{~b} \pm 11$ & \\
\hline 0.3-1 m a.g.l. & 1998 & $21.6 \pm 0.6$ & $54 \mathrm{~b} \pm 35$ & \\
\hline$>1 \mathrm{~m}$ a.g.l. & 1998 & $21.0 \pm 1.0$ & $15 \mathrm{c} \pm 11$ & \\
\hline Several parts & 1998 & $21.6 \pm 4.2$ & $9 c \pm 5$ & \\
\hline Kruskal-Wallis $p^{\text {a }}$ & & $0.366 \mathrm{df}(4, \mathrm{~N} .=17)$ & $0.018 \mathrm{df}(4, \mathrm{~N} .=17)$ & \\
\hline Roots & 2008 & n.a. & 0 & $4 \pm 3.3$ \\
\hline Stem base & 2008 & $30.1 \pm 0.3$ & $77 \mathrm{a} \pm 23$ & 0 \\
\hline $0.3-1 \mathrm{~m}$ a.g.l. & 2008 & $29.6 \pm 1.5$ & $48 \mathrm{a}, \mathrm{b} \pm 23$ & $11 \pm 3.8$ \\
\hline >1 m a.g.l. & 2008 & $29.9 \pm 1.9$ & $10 \mathrm{~b} \pm 5$ & $14 \pm 5.2$ \\
\hline Several parts & 2008 & n.a. & 0 & $9 \pm 2.0$ \\
\hline Kruskal-Wallis $p$ & & $0.874 \mathrm{H}(2, \mathrm{~N} .=12)$ & $0.014 \mathrm{H}(2, \mathrm{~N} .=12)$ & \\
\hline Roots & 2017 & n.a. & 0 & $4 \pm 3.3$ \\
\hline Stem base & 2017 & $35.4 \pm 0.6$ & $75 \mathrm{a} \pm 15$ & $2 \pm 1.2$ \\
\hline $0.3-1 \mathrm{~m}$ a.g.l. & 2017 & $36.1 \pm 0.5$ & $48 \mathrm{~b} \pm 12$ & $11 \pm 3.8$ \\
\hline$>1$ m a.g.l. & 2017 & $35.9 \pm 0.9$ & $10 c \pm 3$ & $14 \pm 5.2$ \\
\hline Several parts & 2017 & n.a. & 0 & $9 \pm 2.0$ \\
\hline Kruskal-Wallis $p$ & & $0.771 \mathrm{df}(2, \mathrm{~N} .=12)$ & $0.021 \mathrm{df}(2, \mathrm{~N} .=12)$ & \\
\hline
\end{tabular}

a Damage to roots and several positions was only found in two and three plots, respectively, in 1998. Different letters show significant differences among positions according to the $\mathrm{K}-\mathrm{W}$ test. Data were recorded in each of the four wound plots. n.a., not available because the trees with damage to either roots or several positions were dead.

Some statistically significant correlations were found in 1998 (agent vs. severity, position vs. severity and agent) and in 2017 (severity vs DBH), but all were characterized by a low value of R, which was always less than 0.4 (Table 6).

The average ring width analysis showed a significant statistical difference among the different periods (Table 7). Data showed that the mean ring width before thinning (BT) was the largest and the mean ring width in the ten years after thinning (TPT1) was the smallest.

Significant differences in the average ring width were found per diameter class, as well as a positive relation between the DBH classes and average ring width. No statistical differences in the average ring width were found for the periods BT and 10 years before thinning (TBT), between trees of the control area, damaged trees, and undamaged trees.

In contrast, significant statistical differences in the average ring width were found for the periods TPT1 and TPT2 in the trees of the control area, with respect to the damaged and undamaged trees. 
Table 6. Correlation matrix among diameter at breast height, damage severity, agent, and position (Spearmann R, $p<0.05$ in bold) after thinning in 1998 (N. = 135), $2008($ N. = 138) and $2017($ N. = 140). Severity, agent, and position were ranked as in Tables 3-5.

\begin{tabular}{cccc}
\hline & DBH & Severity & Agent \\
\hline 1998 & & & \\
Severity & $\mathrm{R}=0.042$ & - & \\
Agent & $\mathrm{R}=0.120$ & $\mathrm{R}=-0.397$ & - \\
Position & $\mathrm{R}=-0.160$ & $\mathrm{R}=0.242$ & $\mathrm{R}=-0.220$ \\
\hline $2008^{\mathrm{a}}$ & & & - \\
Severity & $\mathrm{R}=-0.189$ & - & - \\
Agent & & & \\
Position & $\mathrm{R}=-0.088$ & $\mathrm{R}=0.035$ & - \\
\hline 2017 & & & - \\
Severity & $\mathrm{R}=-0.191$ & - & \\
Position & $\mathrm{R}=-0.082$ & $\mathrm{R}=0.023$ &
\end{tabular}

a In 2008 and 2017, it was not possible to determine the agent of damage in trees that showed late damage. Thus, results refer to severity and position only.

The trends of the yearly average ring width (YWW) for the control and damaged and undamaged trees in the thinned area are shown in Figures 1 and 2. The YWW gradually decreased starting from the 1980s, with a similar trend in the thinned (both damaged and undamaged) and control areas. From 2005 to 2006, a clear change in the trend was shown, with differentiation in the control with respect to undamaged and damaged trees. From 2006, the tree YWW of the control area stopped with a negative trend (Table 8 and Figure 1) but showed a low value and without any major changes until 2017, as also demonstrated from the results of the regression analysis (Figure 2).

The damaged and undamaged trees showed a negative trend until 2004, at which point there was then a change in the trend from 2005, as also demonstrated from the results of the regression analysis (Table 8 and Figure 2).

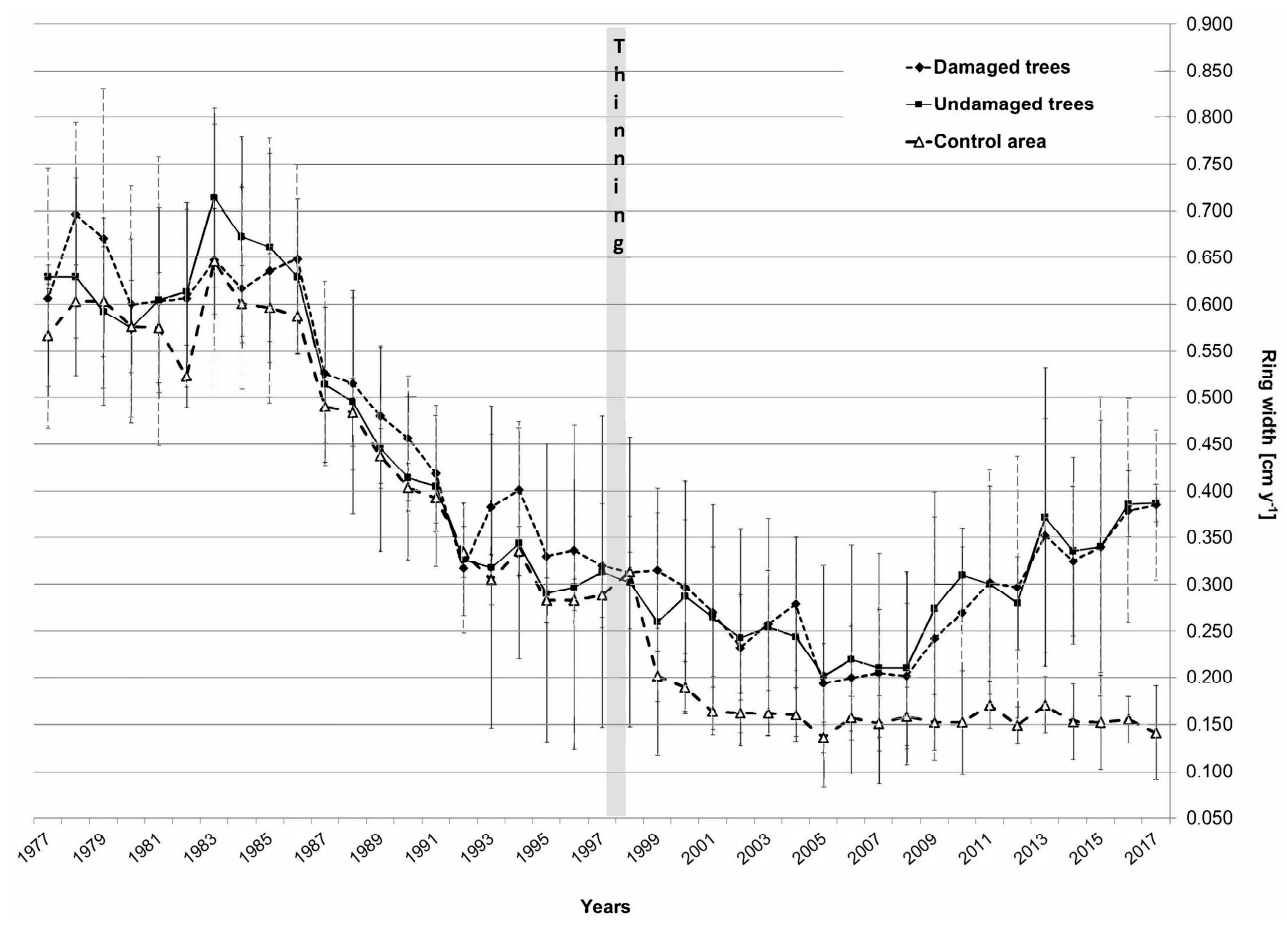

Figure 1. Trend of weighted yearly ring width (YWW) (i.e., the mean of yearly ring width weighted on the basis of the frequency distribution of trees per each diameter class in 2017) from '70s to 2017. 
Table 7. Average ring width per diameter class in control area C (N. $=5$ plots, 7 diameter classes, 2 stem core samples $=70)$ and damaged TD $(\mathrm{N} .=25$ plots, 7 diameter classes, 1 stem core samples $=175)$ and undamaged trees TU (N. $=25$ plots, 7 diameter classes, 1 stem core samples $=175)$ in thinned area over different time periods $($ mean $\pm \mathrm{SD})$.

\begin{tabular}{|c|c|c|c|c|c|c|c|c|}
\hline \multirow{2}{*}{ Time Periods } & \multirow{2}{*}{ Treatment } & \multicolumn{7}{|c|}{ Ring Width $\left(\mathrm{cm}\right.$ year $^{-1}$ ) Per Diameter Class } \\
\hline & & $15-20$ & $20-25$ & $25-30$ & $30-35$ & $35-40$ & $40-45$ & $45-50$ \\
\hline \multirow{3}{*}{$\mathrm{BT}$} & TU & $0.241 \pm 0.06 \mathrm{a}$ & $0.281 \pm 0.05 \mathrm{~d}$ & $0.377 \pm 0.04 \mathrm{f}$ & $0.451 \pm 0.04 \mathrm{~g}$ & $0.482 \pm 0.07 \mathrm{~g}$ & $0.595 \pm 0.09 \mathrm{~h}$ & $0.628 \pm 0.08 \mathrm{~h}, \mathrm{i}$ \\
\hline & $\mathrm{TD}$ & $0.255 \pm 0.09 \mathrm{a}$ & $0.301 \pm 0.02 \mathrm{~d}$ & $0.352 \pm 0.05 \mathrm{f}$ & $0.455 \pm 0.05 \mathrm{~g}$ & $0.507 \pm 0.08 \mathrm{~g}$ & $0.577 \pm 0.09 \mathrm{~h}$ & $0.651 \pm 0.09 \mathrm{i}$ \\
\hline & $\mathrm{C}$ & $0.228 \pm 0.04 \mathrm{a}$ & $0.284 \pm 0.04 \mathrm{~d}$ & $0.369 \pm 0.06 \mathrm{f}$ & $0.437 \pm 0.06 \mathrm{~g}$ & $0.465 \pm 0.08 \mathrm{~g}$ & $0.505 \pm 0.10 \mathrm{~g}$ & $0.608 \pm 0.10 \mathrm{~h}$ \\
\hline \multirow{3}{*}{ TBT } & TU & $0.198 \pm 0.02 b$ & $0.222 \pm 0.03 \mathrm{a}$ & $0.302 \pm 0.02 \mathrm{~d}$ & $0.364 \pm 0.02 \mathrm{f}$ & $0.455 \pm 0.05 \mathrm{~g}$ & $0.505 \pm 0.08 \mathrm{~g}$ & $0.514 \pm 0.08 \mathrm{~g}$ \\
\hline & $\mathrm{TD}$ & $0.192 \pm 0.05 \mathrm{~b}$ & $0.251 \pm 0.06 \mathrm{a}$ & $0.305 \pm 0.05 \mathrm{~d}$ & $0.384 \pm 0.04 \mathrm{f}$ & $0.465 \pm 0.02 \mathrm{~g}$ & $0.511 \pm 0.08 \mathrm{~g}$ & $0.525 \pm 0.08 \mathrm{~g}$ \\
\hline & $\mathrm{C}$ & $0.201 \pm 0.08 \mathrm{~b}$ & $0.212 \pm 0.08 \mathrm{a}$ & $0.283 \pm 0.09 \mathrm{~d}$ & $0.314 \pm 0.08 \mathrm{~d}$ & $0.386 \pm 0.11 \mathrm{f}$ & $0.475 \pm 0.10 \mathrm{~g}$ & $0.490 \pm 0.12 \mathrm{~g}$ \\
\hline \multirow{3}{*}{ TPT1 } & TU & $0.141 \pm 0.09 c$ & $0.168 \pm 0.08 c$ & $0.211 \pm 0.09 \mathrm{a}$ & $0.225 \pm 0.03 \mathrm{a}$ & $0.278 \pm 0.05 \mathrm{~d}$ & $0.315 \pm 0.06 \mathrm{~d}$ & $0.335 \pm 0.05 \mathrm{~d}$ \\
\hline & TD & $0.150 \pm 0.04 \mathrm{c}$ & $0.151 \pm 0.07 \mathrm{c}$ & $0.205 \pm 0.07 \mathrm{a}, \mathrm{b}$ & $0.214 \pm 0.05 \mathrm{a}$ & $0.280 \pm 0.03 \mathrm{~d}$ & $0.327 \pm 0.07 \mathrm{~d}, \mathrm{f}$ & $0.348 \pm 0.07 \mathrm{~d}, \mathrm{f}$ \\
\hline & $\mathrm{C}$ & $0.128 \pm 0.10 \mathrm{c}$ & $0.140 \pm 0.07 c$ & $0.175 \pm 0.07 c$ & $0.195 \pm 0.09 \mathrm{~b}$ & $0.252 \pm 0.07 \mathrm{a}$ & $0.291 \pm 0.09 \mathrm{~d}$ & $0.318 \pm 0.10 \mathrm{~d}$ \\
\hline \multirow{3}{*}{ TPT2 } & $\mathrm{TU}$ & $0.132 \pm 0.10 \mathrm{c}$ & $0.156 \pm 0.09 c$ & $0.210 \pm 0.11 \mathrm{a}$ & $0.238 \pm 0.09 \mathrm{a}$ & $0.298 \pm 0.10 \mathrm{~d}$ & $0.336 \pm 0.16 \mathrm{f}$ & $0.351 \pm 0.07 \mathrm{~d}, \mathrm{f}$ \\
\hline & TD & $0.135 \pm 0.06 \mathrm{c}$ & $0.141 \pm 0.09 c$ & $0.211 \pm 0.09 \mathrm{a}$ & $0.229 \pm 0.08 \mathrm{a}$ & $0.295 \pm 0.13 \mathrm{~d}$ & $0.331 \pm 0.08 \mathrm{~d}, \mathrm{f}$ & $0.350 \pm 0.09 \mathrm{~d}, \mathrm{f}$ \\
\hline & $\mathrm{C}$ & $0.118 \pm 0.15 \mathrm{e}$ & $0.114 \pm 0.05 \mathrm{e}$ & $0.155 \pm 0.09 c$ & $0.184 \pm 0.09 \mathrm{~b}$ & $0.241 \pm 0.08 \mathrm{a}$ & $0.294 \pm 0.11 \mathrm{~d}$ & $0.328 \pm 0.11 \mathrm{~d}$ \\
\hline \multicolumn{2}{|c|}{ ANOVA } & & & & $p$-level & & & \\
\hline \multirow{2}{*}{\multicolumn{2}{|c|}{$\begin{array}{l}\text { Time period } \\
\text { Treatment }\end{array}$}} & & & & 0.019 & & & \\
\hline & & & & & 0.048 & & & \\
\hline \multicolumn{2}{|c|}{ Diameter class } & & & & 0.001 & & & \\
\hline \multicolumn{2}{|c|}{ Time period $\times$ Treatment } & & & & 0.085 & & & \\
\hline \multicolumn{2}{|c|}{ Time period $\times$ Diameter class } & & & & 0.032 & & & \\
\hline \multicolumn{2}{|c|}{ Treatment $\times$ Diameter class } & & & & 0.021 & & & \\
\hline Time period $\times \operatorname{Tr}$ & $\times$ Diameter class & & & & 0.040 & & & \\
\hline
\end{tabular}

BT: all rings before thinning; TBT: ten rings before thinning; post thinning 2008 (ten rings—TPT1); post thinning 2017 (twenty rings—TPT2). Different letters show significant differences among time periods and diameter classes. 
The Wilcoxon non-parametric test showed significant differences after thinning, for the YWW between trees of the control area and damaged trees of the thinned area ( $p$-level 0.008). Similar results were obtained for trees of the control area and undamaged trees of the thinned area ( $p$-level 0.006). Furthermore, no statistically significant difference was exhibited after thinning between damaged and undamaged trees of the thinned area ( $p$-level 0.095).

Table 8. Non-linear regression analysis among ring width (dependent variable) and year (independent variable), for damaged (TD) and undamaged (TU) trees and the trees from the control area (C).

\begin{tabular}{|c|c|c|c|c|}
\hline Typologies & Regression Results & Parameters & Values & $p$-Level \\
\hline $\mathrm{TD}$ & $\begin{array}{c}\mathrm{R}=0.929 ; \mathrm{R}^{2}=0.865 ; \mathrm{R}^{2} \text { adj }=0.862 \\
\mathrm{df}(2,120) ; p<0.001 ; \text { Std. Err.: } 0.057\end{array}$ & $\begin{array}{c}\text { Intercept } \\
\text { year } \\
\text { year }^{2}\end{array}$ & $\begin{array}{c}2223.65906 \\
-2.21614 \\
0.00055\end{array}$ & $\begin{array}{l}<0.001 \\
<0.001 \\
<0.001\end{array}$ \\
\hline $\mathrm{TU}$ & $\begin{array}{c}\mathrm{R}=0.911 ; \mathrm{R}^{2}=0.829 ; \mathrm{R}^{2} \text { adj }=0.826 \\
\mathrm{df}(2,120) ; p<0.001 ; \text { Std. Err.: } 0.064\end{array}$ & $\begin{array}{c}\text { Intercept } \\
\text { year } \\
\text { year }^{2}\end{array}$ & $\begin{array}{c}2422.75717 \\
-2.41617 \\
0.00060\end{array}$ & $\begin{array}{l}<0.001 \\
<0.001 \\
<0.001\end{array}$ \\
\hline $\mathrm{C}$ & $\begin{array}{c}\mathrm{R}=0.957 ; \mathrm{R}^{2}=0.916 ; \mathrm{R}^{2} \text { adj }=0.915 \\
\mathrm{df}(2,120) ; p<0.001 ; \text { Std. Err.: } 0.058\end{array}$ & $\begin{array}{c}\text { Intercept } \\
\text { year } \\
\text { year }^{2}\end{array}$ & $\begin{array}{c}1439.80071 \\
-1.42622 \\
0.00035\end{array}$ & $\begin{array}{l}<0.001 \\
<0.001 \\
<0.001\end{array}$ \\
\hline
\end{tabular}

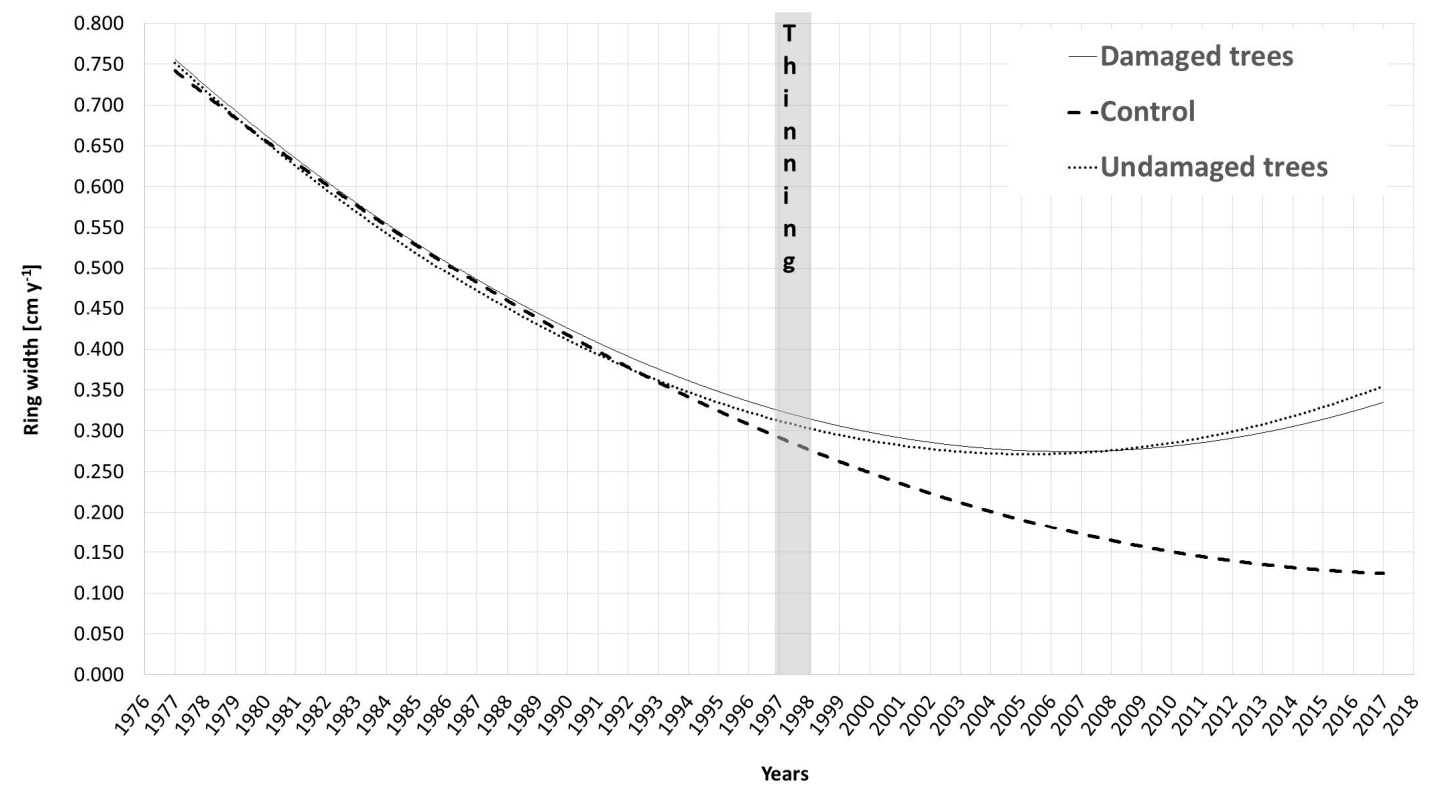

Figure 2. Polynomial regression of weighted yearly ring width (YWW) (i.e., the mean of yearly ring width weighted on the basis of the frequency distribution of trees per each diameter class in 2017) from '70s to 2017. The non-linear regression analysis results are shown in Table 8.

Before thinning, no significant difference was found between the treatments (control, damaged, and undamaged), both in the BT and TBT. After thinning, no significant differences of YWW were found in the thinned area between the damaged and undamaged trees, while the control and thinned area differed significantly, both for damaged ( $p$-level 0.008) and undamaged ( $p$-level 0.006) trees. The non-metric multidimensional scaling (NMDS, Figure 3 ) of the average ring width per diameter class for the 1998 to 2008 (TPT1) interval highlighted that the $C$ area showed the lowest average ring width, while TD and TU showed a slightly higher average ring width, mainly due to the higher DBH classes. The NMDS of the average ring width per diameter class for $\mathrm{C}, \mathrm{TD}$, and TU, focusing on the post thinning period 1998-2017 (TPT2-Figure 4), showed that C had a low average ring width 
in comparison with TU and TD, while TD with respect to TU showed a similar average ring width. From Figures 3 and 4, the increasing difference over time is clearly visible, between C, and TU and TD. Between TD and TU, no difference was shown over time, and they both showed a higher average ring width of the higher DBH classes $(>35 \mathrm{~cm})$ than the trees of the control area.

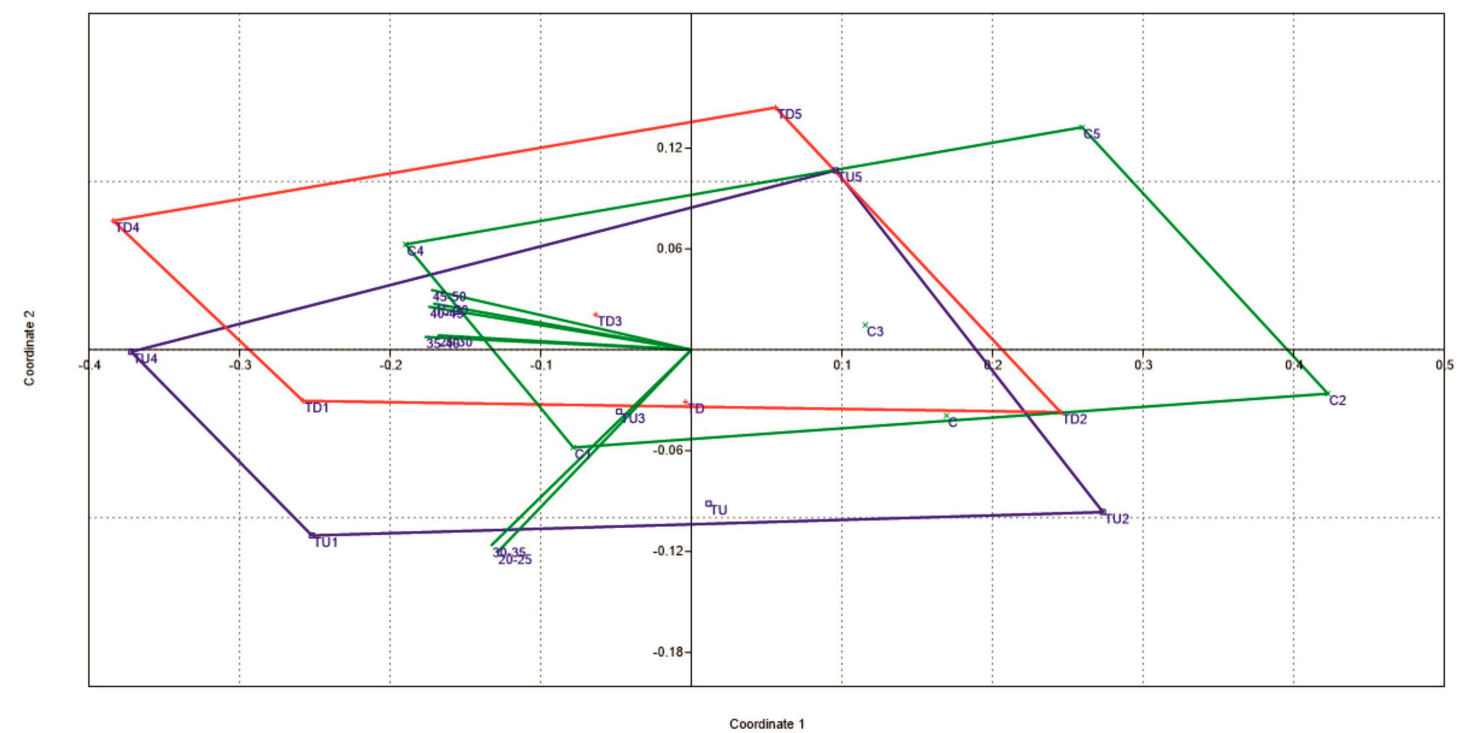

Figure 3. Non-metric multidimensional scaling (NMDS) of the average ring width per diameter class for the trees in the control area $C$ (green polygon, N. $=5$ plots, 7 diameter classes, 2 stem core samples $=70$ ), for damaged trees TD (violet polygon, N. $=25$ plots, 7 diameter classes, 1 stem core samples $=175$ ), and for undamaged trees TU (red polygon, N. $=25$ plots, 7 diameter classes, 1 stem core samples $=175$ ) in the thinned area. The analysis is focused on a specific time period post thinning, from 1998 to 2008 (ten rings-TPT1).

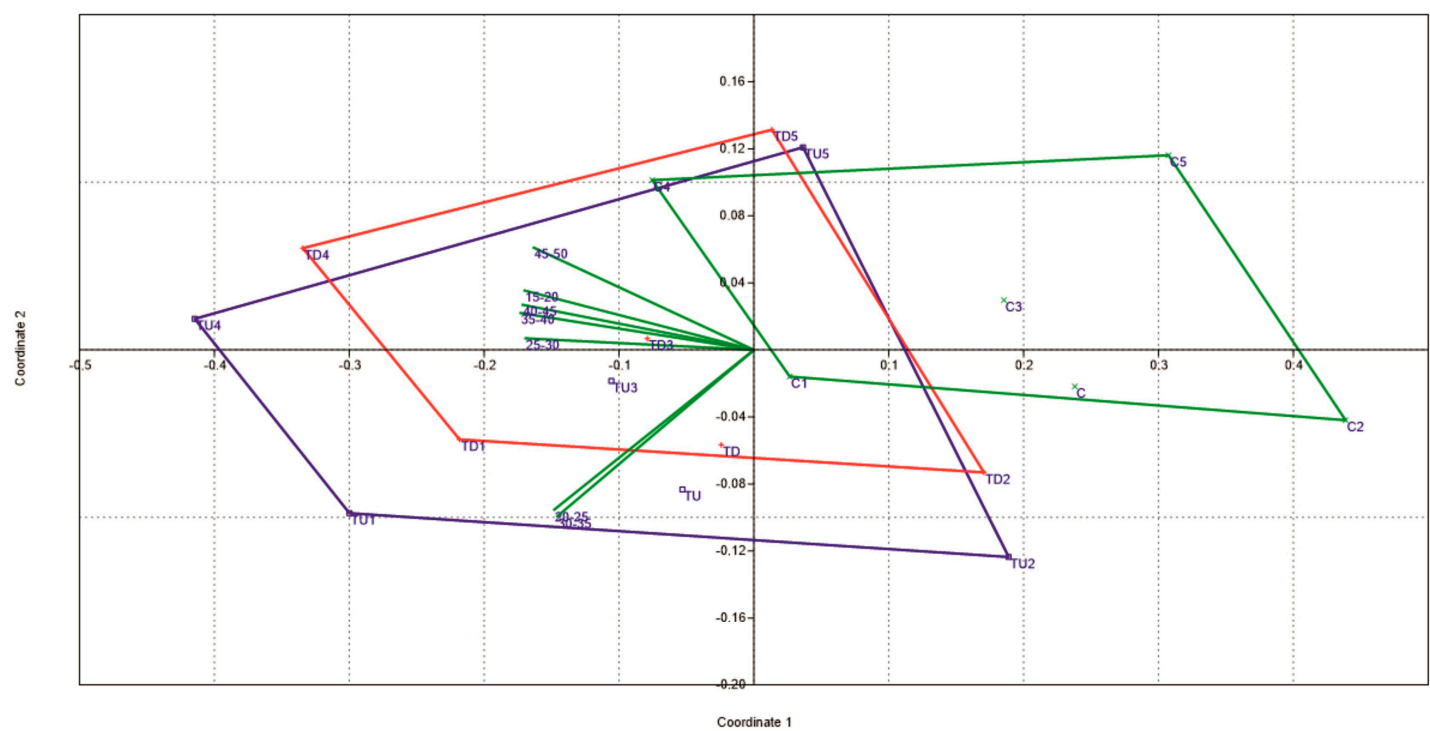

Figure 4. Non-metric multidimensional scaling (NMDS) of the average ring width per diameter class for the trees in the control area C (green polygon, N. $=5$ plots, 7 diameter classes, 2 stem core samples $=70$ ), for damaged trees TD (violet polygon, N. $=25$ plots, 7 diameter classes, 1 stem core samples $=175$ ), and for undamaged trees TU (red polygon, N. $=25$ plots, 7 diameter classes, 1 stem core samples $=175$ ) in the thinned area. The analysis is focused on a specific time period post thinning, from 1998 to 2017 (twenty rings-TPT2). 


\section{Discussion}

This study is a prosecution of a previous one [21] carried out to obtain a long-term analysis of some of the ecological and productive aspects related to thinning in a Pinus laricio Poiret stand in Italy. It also takes into consideration the effects of logging damage and of thinning on stand growth 20 years after the treatment, with an intermediate survey in the year 2008.

The decrease in the basal area recorded in the thinned area in 1998 and 2008 completely changed its trend in 2017. In the same period, the average DBH and height in the treated area were greater than in the control area. The effect of thinning was recorded on each dendrometric parameter as a general rule. Thinning from below forced an increase in mean diameter, directly caused by the removal of the trees with smaller diameters [36]. Ten years after thinning, only a light growing stock increase was shown with respect to the control area. Twenty year later, thinning increased the growing stock significantly. In thinned stands, the tree to tree competition was reduced. The resource redistribution to a lesser number of trees had consequences on the diametric increase of the residual trees, affecting the growing stock [37-39]. The reductions in stand density through thinning had no effect on tree height. As other authors have observed, height growth was less reactive to thinning than diameter [37,40-42]. Twenty years after the thinning, the height of the thinned area and the control showed no statistically significant differences, probably due to the high natural fertility of the site. As demonstrated by some authors, species with higher values of height are associated with the greatest resource availability due to high metabolic demands and biomass accumulation [43,44].

Thinning modified both the stand density and the tree shape. Immediately after thinning, only a slightly lower slenderness ratio was obtained (Table 1), similar to that before thinning, showing a stand stability improvement, but again was very low [34].

Ten years after thinning, the ratio value decreased, suggesting a higher stand stability in comparison to the untreated area. In 2017, this trend was confirmed with a further decrease of the ratio value in comparison to an increase in the untreated area. The slenderness ratio in the thinned area was lower than that found for black pine in central Italy by [45]. The increased tree stability was due to the greater average DBH in the thinned stand rather than height. The age of these stands was the same. The thinning favored larger spaces for the trees, lowering the competition, allowing an increase in diameter both for the technical treatment (thinning from below), and for better allocation of resources. Reference [46] observed that denser stands were more vulnerable to stem breakage due to the high slenderness ratio. The improvement in stability progressed over time after thinning, involving not only the diameter increase, but also the development of the crown.

Only multiple damage led to tree death. Damage to the roots cannot be excluded, as detection is difficult, and may have been the cause of death. However, mortality was mainly caused by wind or snow-throw as no effective presence or evidence that showed causes directly associated with logging wound or operations was detected. The stand achieved better stability in the thinned area. The thinning from below seemed to favor the stand stability in cases of snowfall or wind storm, as by removing the less stable trees, the "domino effect" was avoided [47]. The damaged tree rate was similar to that found in other studies on logging damage in the thinning of conifer stands $[25,48]$. It is interesting to note that the DBH of the damaged trees was significantly higher than the undamaged trees, but only in the first 10 years of the survey.

Lightly damaged trees in 1998 were classified as severely damaged 10 years later, showing a worsening condition that was unchanged in the following period. Moreover, some trees that were classified as undamaged in 1998 were classified as severely damaged in 2017, as non-evident injuries occurred over time [21]. This evidence was apparently conflicting as some trees were impacted during logging operations, but this event did not give rise to injuries or to scrapes on bark. Only sometime after the thinning were undetectable injuries recognized [49].

As shown in [21], the extraction was the main damage agent, as evidenced by the applied equipment (skidding) and logging system (tree length system). In fact, ground-based extraction methods, if not 
supported by adequate technologies and planning, cause higher damage than aerial-based methods (i.e., cable yarder) $[24,35,48,50]$, and the shorter the logs, the lower the damage [51,52].

As found from the analysis up to 2017, no wound was completely healed, while partially healed wounds comprised about $30 \%$ of the damaged trees. As found by [27], the wound healing rate is influenced by tree species, tree growth and vigor, and wound characteristics. The authors in [25] suggested a $25-50$ year healing period for a $10 \mathrm{~cm}$ wide wound in Norway spruce. Reference [53] indicated a 15-year period for the complete healing of $<60 \mathrm{~cm}^{2}$ wounds in Sitka spruce. The commercial value of these pine plantations is not the main objective today, but pinewood has a role in ecosystem services such as soil protection, landscape, and social services. However, injuries can affect the potential forest efficiency. Diseases and insect infestations may afflict trees in an unhealthy physiological condition. Logging injuries to the roots or at the lower part of the bole are easy access points for biological attacks $[27,54-56]$, and in our case, death causing agents.

This result suggests that logging damage does not affect the radial growth of $P$. laricio over time, at least up to 40 years of age. However, some species seems to be more susceptible to logging damage. In Norway spruce, a growth reduction of about $10-30 \%$ was observed [57-59], even in height. Scots pine suffered a mean diameter increment reduction of $12.3 \%$ [60]. In lime trees, diameter growth was dramatically affected by wounds, decreasing as much as $43 \%$, thus increasing injury severity [61]. In Alder, wounds significantly reduced diameter growth [62]. Other authors have highlighted the lack of difference in damaged or undamaged trees. Reference [63] underlined that ponderosa and lodgepole pine, three years after artificial wounding, showed higher healing rates in the thinned area, but no significant difference in diameter growth was observed between trees in the thinned and control areas. They observed that no decay occurred in wounded pine, while it frequently occurred in grand fir. On Pinus pinaster trees, scarred by debris transported during flash floods, [64] noticed that ring widths of the disturbed trees decreased dramatically near the injuries, but on the opposite site, ring widths were not significantly different.

Damage to roots is difficult to detect since soil modification can be arduous to quantify in relation to single trees. Root injuries can reduce the radial and height increment of Norway spruce more than stem injuries [59].

However, there are many factors that may explain the difference between our results and those of most of the other previous studies. First of all, the species and geographic area, the Mediterranean area in our study, and North-Europe in most of the other studies, may affect the results. In a recent study on Norway spruce and Scots pine, [32] did not find any relation between artificial damage and radial, height, or volume increment.

All treatments (damaged, undamaged, and control trees) showed a reduction over time of average ring width, in the periods BT and TPT1. However, the different trend in the yearly average ring width (YWW) after thinning highlighted that at the stand level, the growth was higher in the thinned area than in the control area. The delay of about seven years in the growth response after thinning was also found by other authors $[19,20]$ and corresponded to a short-term decline in the growth of remaining trees, called "thinning shock". After this phenomenon, a clear recovery of growth started.

\section{Conclusions}

The results of the first step of this investigation [21] suggested that more specific studies on this topic were needed, as well as an effective assessment of logging damage to be made over long time periods. In this study, logging damage was monitored and the effects of thinning on stand growth were evaluated in the 20 years after the treatment.

These analyses were done for a better comprehension of the ecological and productive aspects due to the management of pine forests, in a Pinus laricio Poiret stand in Central Italy. In detail, the aims were: 
- to assess the stand dynamics in relation to the injury levels and the treatment applied in a twenty-year range: in about twenty years after the treatment, the stand dynamics showed a complete recovery, and associated implementations, of growth and stability characteristics, independent from the logging injury;

- to evaluate the effect of damage on the radial growth of trees: the results found suggested that logging damage did not affect the radial growth of $P$. laricio over time;

- to try to understand a possible treatment return time and evaluate the existence of the "thinning shock" situation: in consideration of what was found, a second treatment seemed to be sustainable starting from the fifteenth year after the previous treatment. Regarding thinning shock, this can be clearly evaluated in the tree ring width in the first six to seven years after the treatment.

The findings are key factors in the ecological management of Corsican pine forest located in the Mediterranean area and an important reading vital to supporting the decision making of forest managers. In addition, from this case study, some suggestions are proposed to reduce the impact during logging in the thinning of pine stands: (i) promote environmentally responsible and locally acceptable forest mechanization levels; (ii) invest in workforce training that improves not only operational skills, but also an awareness of ecological and environmental issues; (iii) the selection of an adequate timber extraction system during silvicultural planning; (iv) pursue detailed operational planning to reduce potential negative impacts and improve their economic efficiency and safety; and (v) make a multitasking plan based on a close dialogue between sustainable forest management and sustainable forest operations.

Furthermore, for proper ecological management, as well as for an active forest management of pine forests, pragmatic harvesting guidelines and best management practices will be needed. This approach could minimize negative impacts related to active management practices.

Author Contributions: Conceptualization: R.P. and E.M.; Methodology: R.P., R.V. and A.L.M.; Validation: R.P., R.V. and F.L.; Investigation: R.P., R.V., F.L. and A.L.; Data Curation: R.P., R.V., A.L.M.; Writing-Original Draft Preparation: R.P., R.V., E.M., A.L. and A.L.M.; Writing-Review \& Editing: R.P. and E.M.; Supervision: R.P., E.M. and A.L.M.

Conflicts of Interest: The authors declare no conflict of interest.

\section{References}

1. Kint, V.; Mohren, G.M.J.; Geudens, G.; De Wulf, R.; Lust, N. Pathways of stand development in ageing Pinus sylvestris forests. J. Veg. Sci. 2004, 15, 549-560. [CrossRef]

2. Zenner, E.K.; Hibbs, D.E. A new method for modeling the heterogeneity of forest structure. For. Ecol. Manag. 2000, 129, 75-87. [CrossRef]

3. Chiavetta, U.; Skudnik, M.; Becagli, C.; Bertini, G.; Ferretti, F.; Cantiani, P.; Di Salvatore, U.; Fabbio, G. Diversity of structure through silviculture. Ital. J. Agron. 2016, 11, 1-175.

4. Corona, P.; Ascoli, D.; Barbati, A.; Bovio, G.; Colangelo, G.; Elia, M.; Garfi, V.; Iovino, F.; Lafortezza, R.; Leone, V.; et al. Integrated forest management to prevent wildfires under Mediterranean environments. Ann. Silvic. Res. 2015, 39, 1-22.

5. Kerr, G.; Hauf, J. Thinning Practice. A Silvicultural Guide. Version 1.0. January 2011. Forestry Commission. Available online: http://www.forestry.gov.uk/pdf/Silviculture_Thinning_Guide_v1_Jan2011.pdf/\$FILE/ Silviculture_Thinning_Guide_v1_Jan2011.pdf (accessed on 1 February 2011).

6. Barbero, M.; Bonin, G.; Loisel, R.; Quézel, P. Changes and disturbances of forest ecosystems caused by human activities in the western part of the Mediterranean Basin. Vegetatio 1990, 87, 151-173. [CrossRef]

7. Ortuño, F. El plan para la repoblación forestal de España del año 1939. Análisis y comentarios. Ecol. Fuera Ser. 1990, 1, 373-392.

8. Marchi, M.; Paletto, A.; Cantiani, P.; Bianchetto, E.; De Meo, I. Comparing Thinning Systems Effects on Ecosystem 2 Services Provision in Black Pine (Pinus nigra J.F. Arnold) Artificial Forests. Forests 2018, 9, 188. [CrossRef] 
9. Kovats, R.S.; Valentini, R.; Brower, L.M.; Georgopoulou, E.; Jacob, D.; Martin, E.; Rounsevell, M.; Soussana, J.-F. Climate Change 2014: Impacts, Adaptation, and Vulnerability. Part B: Regional Aspects; Contribution of Working Group II to the Fifth Assessment Report of the Intergovernmental Panel on Climate Change; Cambridge University Press: Cambridge, UK; New York, NY, USA, 2014; pp. 1267-1326.

10. Moriondo, M.; Good, P.; Durao, R.; Bindi, M.; Giannakopoulos, C.; Corte Real, J. Potential impact of climate change on fire risk in the Mediterranean area. Clim. Res. 2006, 31, 85-95. [CrossRef]

11. Lindner, M.; Garcia-Gonzalo, J.; Kolström, M.; Green, T.; Reguera, R.; Maroschek, M.; Seidl, R.; Lexer, M.J.; Netherer, S.; Schopf, A.; et al. Impacts of Climate Change on European Forests and Options for Adaptation. Report to the European Commission Directorate-General for Agriculture and Rural Development. 2008. Available online: https://ec.europa.eu/agriculture/external-studies/euro-forests_en (accessed on 20 January 2018).

12. Gavinet, J.; Vilagrosa, A.; Chirino, E.; Granados, M.E.; Vallejo, V.R.; Prévosto, B. Hardwood seedling establishment below Aleppo pine depends on thinning intensity in two Mediterranean sites. Ann. For. Sci. 2015, 72, 999-1008. [CrossRef]

13. Park, J.; Kim, T.; Moon, M.; Cho, S.; Ryu, D.; Seok Kim, H. Effects of thinning intensities on tree water use, growth, and resultant water use efficiency of 50-year-old Pinus koraiensis forest over four years. For. Ecol. Manag. 2018, 408, 121-128. [CrossRef]

14. Breda, N.; Granier, A.; Aussenac, G. Effects of thinning on soil and tree water relations, transpiration and growth in an oak forest (Quercus petraea (Matt.) Liebl.). Tree Physiol. 1995, 15, 295-306. [CrossRef] [PubMed]

15. Aussenac, G. Interactions between forest stands and microclimate: Ecophysiological aspects and consequences for silviculture. Ann. For. Sci. 2000, 57, 287-301. [CrossRef]

16. Ganatsios, H.P.; Tsioras, P.A.; Pavlidis, T. Water yield changes as a result of silvicultural treatments in an oak ecosystem. For. Ecol. Manag. 2010, 260, 1367-1374. [CrossRef]

17. Jutras, S.; Plamondon, A.P.; Hokka, H.; Begin, J. Water table changes following precommercial thinning on post-harvest drained wetlands. For. Ecol. Manag. 2006, 235, 252-259. [CrossRef]

18. Gebhardt, T.; Häberle, K.-H.; Matyssek, R.; Schulz, C.; Ammer, C. The more, the better? Water relations of Norway spruce stands after progressive thinning. Agric. For. Meteorol. 2014, 197, 235-243. [CrossRef]

19. Harrington, C.A.; Reukema, D.L. Initial shock and long-term stand development following thinning in a Douglas-fir plantation. For. Sci. 1983, 29, 33-46.

20. Dore, S.; Montes-Helu, M.; Hart, S.C.; Hungate, B.A.; Koch, G.W.; Moon, J.B.; Finkral, A.J.; Kolb, T.E. Recovery of ponderosa pine ecosystem carbon and water fluxes from thinning and stand-replacing fire. Glob. Chang. Biol. 2012, 18, 3171-3185. [CrossRef] [PubMed]

21. Picchio, R.; Neri, F.; Maesano, M.; Savelli, S.; Sirna, A.; Blasi, S.; Baldini, S.; Marchi, E. Growth effects of thinning damage in a Corsican pine (Pinus laricio Poiret) stand in central Italy. For. Ecol. Manag. 2011, 262, 237-243. [CrossRef]

22. Zhang, Q.; Alfaro, R.I.; Hebda, R.J. Dendroecological studies of tree growth, climate and spruce beetle outbreaks in Central British Columbia, Canada. For. Ecol. Manag. 1999, 121, 215-225. [CrossRef]

23. Larson, A.J.; Franklin, J.F. The tree mortality regime in temperate old-growth coniferous forests: The role of physical damage. Can. J. For. Res. 2010, 40, 2091-2103. [CrossRef]

24. Picchio, R.; Spina, R.; Calienno, L.; Venanzi, R.; Lo Monaco, A. Forest operations for implementing silvicultural treatments for multiple purposes. Ital. J. Agron. 2016, 11, 156-161.

25. Vasiliauskas, R. Damage to trees due to forestry operation and its pathological significance in temperate forests: A literature review. Forestry 2001, 74, 319-336. [CrossRef]

26. Bertolotto, P.; Calienno, L.; Conforti, M.; D’Andrea, E.; Lo Monaco, A.; Magnani, E.; Marinšek, A.; Micali, M.; Picchio, R.; Sicuriello, F.; et al. Assessing indicators of forest ecosystem health. Ann. Silvic. Res. 2016, 40, 64-69.

27. Tavankar, F.; Picchio, R.; Nikooy, M.; Lo Monaco, A.; Venanzi, R.; Iranparast Bodaghi, A. Healing rate of logging wounds on broadleaf trees in Hyrcanian forest with some technological implications. Drewno 2017, 60, 65-80. [CrossRef]

28. Lutz, J.; Halpern, C. Tree Mortality during Early Forest Development: A Long-Term Study of Rates, Causes, and Consequences. Ecol. Monogr. 2006, 76, 257-275. [CrossRef]

29. Mäkinen, H.; Hallaksela, A.M.; Isomäki, A. Increment and decay in Norway spruce and Scots pine after artificial logging damage. Can. J. For. Res. 2007, 37, 2130-2141. [CrossRef] 
30. Zhang, J.W.; Webster, J.; Young, D.H.; Fiddler, G.O. Effect of thinning and soil treatments on Pinus ponderosa plantations: 15-year results. For. Ecol. Manag. 2016, 368, 123-132. [CrossRef]

31. Fontana, G.; Cherubini, P.; Rigling, D.; Dobbertin, M.; Brang, P.; Innes, J.L. Ricostruzione della storia di un popolamento di pino montano (Pinus mugo Turra) nel Parco Nazionale Svizzero: Gli anelli annuali testimoni di azioni di disturbo antropiche e naturali. Monti e Boschi 2003, 6, 34-39.

32. Hurlbert, S.H. Pseudorepliction and the design of ecological field experiments. Ecol. Monogr. 1984, 54, $187-211$. [CrossRef]

33. Hermanin, L.; Sani, L. Indagini sulla produzione del pino laricio in Toscana. Annali dell'Istituto Sperimentale per la Selvicoltura 1989, 20, 571-600.

34. La Marca, O. Il problema degli schianti nei boschi. Ricerche sperimentali su alcuni popolamenti di conifere. Ann. Acad. Ital. Sci. For. 1983, 32, 69-114.

35. Picchio, R.; Neri, F.; Petrini, E.; Verani, S.; Marchi, E.; Certini, G. Machinery-induced soil compaction in thinning two pine stands in central Italy. For. Ecol. Manag. 2012, 285, 38-43. [CrossRef]

36. Mäkinen, H.; Isomäki, A. Thinning intensity and long-term changes in increment and stem form of Scots pine trees. For. Ecol. Manag. 2004, 203, 21-34. [CrossRef]

37. Mäkinen, H.; Isomäki, A. Thinning intensity and growth of Scots pine stands in Finland. For. Ecol. Manag. 2004, 201, 311-325. [CrossRef]

38. Martin-Benito, D.; Kint, V.; del Río, M.; Muys, B.; Cañellas, I. Growth responses of West-Mediterranean Pinus nigra to climate change are modulated by competition and productivity: Past trends and future perspectives. For. Ecol. Manag. 2011, 262, 1030-1040. [CrossRef]

39. Sohn, J.A.; Gebhardt, T.; Ammer, C.; Bauhus, J.; Häberle, K.-H.; Matyssek, R.; Grams, T.E.E. Mitigation of drought by thinning: Short-term and long-term effects on growth and physiological performance of Norway spruce (Picea abies). Ann. For. Sci. 2008, 65, 308. [CrossRef]

40. Del Río, M.; Calama, R.; Cañellas, I.; Roig, S.; Montero, G. Thinning intensity and growth response in SW-European Scots pine stands. Ann. For. Sci. 2008, 65, 308. [CrossRef]

41. Peterson, J.A.; Seiler, J.R.; Nowak, J.; Ginn, S.E.; Kreh, R.E. Growth and physiological responses of young loblolly pine stands to thinning. For. Sci. 1997, 43, 529-534.

42. Oliver, W.W. Growth after Thinning Ponderosa and Jeffrey Pine Pole Stands in Northeastern California; USDA Forest Service Research Paper PSW-85; Pacific Southwest Forest and Range Experiment Station: Berkeley, CA, USA, 1972.

43. Oliveira-Filho, A.T.; Curi, N.; Vilela, E.A.; Carvalho, D.A. Variation in tree community composition and structure with changes in soil properties within a fragment of semideciduous forest in South-eastern Brazil. Edinb. J. Bot. 2001, 58, 139-158. [CrossRef]

44. Coelho, M.S.; Carlos, P.P.; Pinto, V.D.; Meireles, A.; Negreiros, D.; Morellato, L.P.C.; Fernandes, G.W. Connection between tree functional traits and environmental parameters in an archipelago of montane forests surrounded by rupestrian grasslands. Flora: Morphology, Distribution. Funct. Ecol. Plants 2018, 238, 51-59. [CrossRef]

45. Cantiani, P.; Chiavetta, U. Estimating the mechanical stability of Pinus nigra Arn. using an alternative approach across several plantations in central Italy. iForest 2015, 8, 846-852. [CrossRef]

46. Nykänen, M.-L.; Peltola, H.; Quine, C.P.; Kellomäki, S.; Broadgate, M. Factors affecting snow damage of trees with particular reference to European conditions. Silva Fenn. 1997, 31, 193-213. [CrossRef]

47. Del Río, M.; Bravo-Oviedo, A.; Pretzsch, H.; Löf, M.; Ruiz-Peinado, R. A review of thinning effects on Scots pine stands: From growth and yield to new challenges under global change. For. Syst. 2017, 26, 3. [CrossRef]

48. Spinelli, R.; Magagnotti, N.; Nati, C. Benchmarking the impact of traditional small-scale logging systems used in Mediterranean forestry. For. Ecol. Manag. 2010, 260, 1997-2001. [CrossRef]

49. Legere, G. Reduction of stem damage by integrating skidding with declaiming. For. Eng. Res. Inst. Can. 2001, 2, 1-19.

50. Marchi, E.; Picchio, R.; Spinelli, R.; Verani, S.; Venanzi, R.; Certini, G. Environmental impact assessment of different logging methods in pine forests thinning. Ecol. Eng. 2014, 70, 429-436. [CrossRef]

51. Matzka, P.J.; Kellogg, L.D. Harvest System Selection and Design for Damage Reduction in Noble Fir Stands: A Case Study on the Warm Springs Indian Reservation, Oregon. West. J. Appl. For. 2003, 18, 118-126. 
52. Bakinowska, E.; Szczepańska-Álvarez, A.; Mederski, P.S.; Karaszewski, Z.; Bembenek, M. Parallel application of two probability models, logit and probit, for accurate analysis of spruce timber damage due to thinning operations. Drewno 2016, 59, 49-59. [CrossRef]

53. Welch, D.; Scott, D.; Staines, B.W. Bark stripping damage by red deer in a Sitka spruce forest in Western Scotland. III. Trends in wound condition. Forestry 1997, 70, 113-120. [CrossRef]

54. Bettinger, P.; Kellogg, L. Residual stand damage from cut-to-length thinning of second growth timber in the Cascade Range of western Oregon. For. Prod. J. 1993, 43, 59-64.

55. Camp, A. Damage to residual trees by four mechanized harvest systems operating in small diameter, mixed conifer forests and steep slopes in northeastern Washington: A case study. West. J. Appl. For. 2002, 17, 14-22.

56. Annesi, T.; Calienno, L.; Picchio, R.; De Simone, D.; Lo Monaco, A. Degradation of some technological features in the wood of ornamental species caused by Inonotus rickii (Pat.) Reid. Drewno 2015, 58, 5-18. [CrossRef]

57. Baader, G. Damage by game in Rheinland-Pfalz and the possibilities to minimize it. Allg. For. Jagdztg. 1956, 127, 190-212.

58. Vanek, J. Orientacni studio nasledku loupani lesnich porostu zveri. Lesictvi 1956, 3, 59-78.

59. Isomäki, A.; Kallio, T. Consequences of injury caused by timber harvesting machines on the growth and decay of spruce (Picea abies (L.) KARST.). Acta For. Fenn. 1974, 136, 1-24. [CrossRef]

60. Andersson, S.-O. Om lövröjning i plant-och ungskogar. Sveriges Skogsvaardsfoerbunds Tidskrift 1984, 82, 69-95.

61. Tavankar, F.; Lo Monaco, A.; Picchio, R.; Venanzi, R.; Nikooy, M. Healing ability and diameter growth of lime-trees (Tilia begonifolia Stev.) following logging wounds. Eur. J. For. Res. 2018, 137, 1-11. [CrossRef]

62. Tavankar, F.; Nikooy, M.; Picchio, R.; Bonyad, A.; Venanzi, R. Effects of logging wounds on Caucasian Alder trees (Alnus subcordata C.A. Mey.) in Iranian Caspian Forests. Croat. J. For. Eng. 2017, 38, 73-82.

63. Filip, G.M.; Parks, C.A.; Wickman, B.E.; Mitchell, R.G. Tree Wound Dynamics in Thinned and Unthinned Stands of Grand Fir, Ponderosa Pine, and Lodgepole Pine in Eastern Oregon. Northwest Sci. 1995, 69, $276-283$.

64. Ballesteros, J.A.; Stoffel, M.; Bodoque, J.M.; Bollschweiler, M.; Hitz, O.; Díez-Herrero, A. Changes in Wood Anatomy in Tree Rings of Pinus pinaster Ait. Following Wounding by Flash Floods. Tree-Ring Res. 2010, 66, 93-103. [CrossRef] 